\title{
NUTRITIONAL, IMMUNOLOGICAL AND MICROBIOLOGICAL PROFILES OF BURN PATIENTS
}

\section{Barbosa ASAA (1), Calvi SA (1), Pereira PCM (1)}

(1) Department of Tropical Diseases, Botucatu Medical School, São Paulo State University, UNESP, Botucatu, São Paulo State, Brazil.

\begin{abstract}
A burn is a lesion on an organic tissue resultant from direct or indirect action of heat on the organism. The present study aimed to evaluate the nutritional, immunological and microbiological status of burn patients at the Bauru State Hospital, São Paulo state, Brazil, in 2007. Eight patients, aged more than 18 years and injured up to 24 hours, were evaluated at the moment of hospitalization and seven days later. All victims were males with a mean age of 38 years. On average, $17.5 \%$ of their body surfaces were burned and $50 \%$ of the patients were eutrophic. There were significant alterations in levels of erythrocytes, hemoglobin, hematocrit, total protein and albumin due to increased endothelial permeability, direct destruction of proteins in the heat-affected area and blood loss from lesions or debridement. At a second moment, cytokines IL-6 and TNF- $\alpha$ had augmented significantly, with IL-6 presenting elevated levels in relation to controls at the first moment. Microbiological analysis showed that $100 \%$ of the samples collected at hospital admission were negative and after one week Staphylococcus aureus was found in all cultures. Therefore, a burn patient may be considered immunosuppressed and these results indicate significant nutritional, immunological and microbiological alterations that can interfere in his recovery.
\end{abstract}

KEY WORDS: burn, nutrition, infection, TNF-a, IL-6, laboratory exams.

CONFLICTS OF INTEREST: There is no conflict.

\section{CORRESPONDENCE TO:}

PAULO CÂMARA MARQUES PEREIRA, Departamento de Doenças Tropicais,

Faculdade de Medicina de Botucatu, UNESP, Distrito de Rubião Jr, s/n, Botucatu, SP, 18618-000, Brasil. Email: ppereira@fmb.unesp.br. 


\section{INTRODUCTION}

A burn is an injury to an organic tissue caused by direct or indirect action of heat by means of exposure to flames, heated liquids, contact with hot objects, exposure to corrosive chemicals, radiation or contact with an electric current $(1,2)$. According to the Brazilian Society of Burn Injuries, one million burn cases occur in the country per year; 200,000 of which are treated in emergency rooms, while 40,000 require hospitalization (2). A burn provokes profound metabolic alterations, including malnutrition and hypermetabolism (3). This injury is accompanied by pathophysiological changes that induce acute inflammatory response characterized by activation of inflammatory mechanisms, disruption of cellular immunity and alterations of immune system mediators that, in turn, involve activation of TNF- $\alpha$, IL1 , IL-6 and IL-8. These cytokines play a key role in amplifying the inflammatory response and have been proven to be connected to morbidity and mortality in these patients (4). Infection is one of the main causes of death among burn victims. Thus, rapid diagnosis and treatment of infections, by isolating microorganisms at the infection site, are indispensable (5). For this reason, the present study aimed to evaluate the repercussion of burns in relation to the nutritional, immunological and microbiological profile of patients hospitalized with a burn diagnosis.

The participants were fully informed about the details of the study and signed terms of free and informed consent. The project was approved by the Research Ethics Committee of the Lauro de Souza Lima Institute, Bauru, São Paulo state, Brazil.

Eight hospitalized patients were evaluated, up to 24 hours after the injury, at the Burn Unit of the Bauru State Hospital, Brazil, from May to September 2007. For cytokine analysis, a control group of 20 normal individuals - blood donors of both genders, aged more than 18 years, from the Botucatu Medical School, UNESP - was employed. All burned individuals were examined at the moment of hospitalization $\left(M_{0}\right)$ and seven days after $\left(M_{1}\right)$. Evaluations comprised the following clinical and epidemiological aspects: age, formal education level, burn degree, percentage of burned body surface, body regions burned, causal agent and the nature and location of the accident. The nutritional evaluation included: weight, height, body mass index (BMI) and nutritional diagnosis.

Laboratory tests assessed microbiological samples collected from the oral, nasal, rectal and axillary regions. The swab was placed on Stuart's transport medium then cultured on blood, manitol and MacConkey media, and, finally, incubated for 24 
hours at $37^{\circ} \mathrm{C}$. Each isolate was identified using the conventional protocol standardized by the Laboratory of Clinical Analyses at the Bauru State Hospital. For blood tests, $10 \mathrm{~mL}$ of venous blood was collected to perform biochemical and hematological procedures. To determine the serum cytokine levels, blood samples were centrifuged, aliquoted and stored at $-80^{\circ} \mathrm{C}$. The cytokines TFN- $\alpha$ and IL-6 were quantified by ELISA utilizing commercial Quantikine Human kits ${ }^{\circledR}$ (R\&D Systems, USA). Statistical analysis employed the Wilcoxon test and the paired t-test with the aid of $S A S \circledR$ software for Windows, version $9.1 ; p<0.05$ was significant.

Table 1 reveals that all studied individuals were males, a fact attributed to the greater exposure of men to high-risk activities, while the mean age was 38 years, which coincided with activities in which young adults are more prone to suffer accidents (6). Fifty percent of the patients had more than $20 \%$ of their body surface burned. The general risk within the first hours after burn injuries depends, fundamentally, on the extent of the burned area, so that the larger the affected area the greater the systemic repercussion due to loss of skin functions $(6,7)$.

Fire represented the main causal agent and was responsible for $75 \%$ of the accidents. Burns provoked by alcohol are more profound than those caused by scalding, since the time of exposure to heat in burns by flammable liquid is longer ( 8 , 9). Nutritional status has been reported, in various studies, as an important factor in recovery of burn patients by reducing complications and rates of morbidity and mortality, which are generally elevated in these patients (9-14). The mean height of patients was $1.67 \mathrm{~m}$, while average weight was $73.86 \mathrm{~kg}$ and BMI was $25.81 \mathrm{~kg} / \mathrm{m}^{2}$. The nutritional diagnosis at the moment of hospitalization revealed that $50.0 \%$ of cases were eutrophic, $37.5 \%$ were overweight, and $12.5 \%$ were obese. These findings corroborate previous studies that describe this distribution in burn victims (914). 
Table 1. Demographics of patients

\begin{tabular}{c|c|c|c|c|c|c|c|c}
\hline Patients & Sex & $\begin{array}{c}\text { Age } \\
(\mathbf{y e a r s})\end{array}$ & TBSA & $\begin{array}{c}\text { Causes } \\
\text { of burns }\end{array}$ & $\begin{array}{c}\text { Height } \\
(\mathbf{m})\end{array}$ & $\begin{array}{c}\text { Weight } \\
\mathbf{( k g )}\end{array}$ & $\begin{array}{c}\text { BMI } \\
\left(\mathbf{k g} / \mathbf{m}^{2}\right)\end{array}$ & $\begin{array}{c}\text { Nutritional } \\
\text { diagnosis }\end{array}$ \\
\hline 1 & $\mathrm{M}$ & 32 & 34 & Flames & 1.6 & 79 & 29 & Mild obesity \\
\hline 2 & $\mathrm{M}$ & 57 & 27 & Flames & 1.76 & 85 & 27.4 & Mild obesity \\
\hline 3 & $\mathrm{M}$ & 55 & 5 & Electricity & 1.6 & 60 & 23.4 & Normal \\
\hline 4 & $\mathrm{M}$ & 31 & 9 & Flames & 1.76 & 75 & 24.3 & Normal \\
\hline 5 & $\mathrm{M}$ & 36 & 15 & Flames & 1.76 & 98 & 31.7 & Obesity \\
\hline 6 & $\mathrm{M}$ & 21 & 23 & Flames & 1.65 & 70 & 25.7 & Mild obesity \\
\hline 7 & $\mathrm{M}$ & 29 & 6 & Flames & 1.6 & 58.9 & 23 & Normal \\
\hline 8 & $\mathrm{M}$ & 48 & 20 & Scalding & 1.7 & 65 & 22 & Normal \\
\hline
\end{tabular}

TBSA: burned surface area; BMI: body mass index.

An important factor that indirectly affects life conditions of the studied population, which can be related to nutritional behavior, is the low level of formal education (Table 2). In the present study, the most prevalent study level was basic education (6). Fifty percent of the victims presented an association of second and third degree burns (5). With regard to the nature of the incident, the fact that the current study included only adults must have contributed to the predominance of accidental origin and work accidents. Residences and workplaces were the most frequent burn localities, in agreement with other studies (8). 
Table 2. Clinical evaluation of variables

\begin{tabular}{|c|c|c|}
\hline Variable & Patients & 'ercentage (\%) \\
\hline \multicolumn{3}{|l|}{ Study level } \\
\hline Incomplete basic education & 2 & 25.0 \\
\hline Complete basic education & 4 & 50.0 \\
\hline Incomplete high school education & 1 & 12.5 \\
\hline Complete higher education & 1 & 12.5 \\
\hline \multicolumn{3}{|l|}{ Burn degree } \\
\hline $1^{\text {st }}$ and $2^{\text {nd }}$ & 2 & 25.0 \\
\hline $2^{\text {nd }}$ & 2 & 25.0 \\
\hline $2^{\text {nd }}$ and $3^{\text {rd }}$ & 4 & 50.0 \\
\hline \multicolumn{3}{|l|}{ Burned body region } \\
\hline CPTMIS & 3 & 37.5 \\
\hline CTMS & 1 & 12.5 \\
\hline MI & 2 & 25.0 \\
\hline MIS & 1 & 12.5 \\
\hline TMS & 1 & 12.5 \\
\hline \multicolumn{3}{|l|}{ Nature of incident } \\
\hline Accidental (non-work accidents) & 3 & 37.5 \\
\hline Work accident & 3 & 37.5 \\
\hline Crime & 2 & 25.0 \\
\hline \multicolumn{3}{|l|}{ Place of incident } \\
\hline House & 4 & 50.0 \\
\hline Street & 1 & 12.5 \\
\hline Work & 3 & 37.5 \\
\hline
\end{tabular}

CPTMIS: head, neck, trunk, lower and upper limbs; CTMS: head, trunk and upper limbs; MI: lower limbs; MIS: lower and upper limbs; TMS: trunk and upper limbs.

Table 3 presents the results of laboratory exams in which albumin and total protein were reduced, as expected, due to augmented endothelial permeability, protein catabolism and direct destruction of proteins in the affected area, as described in 
previous studies (15-17). Serum erythrocytes, hemoglobin and hematocrit, in the present study, had dropped by the second moment, subsequent to blood loss from curatives or debridement. The white blood cell count is important in clinical monitoring, and deviation of the count toward more immature neutrophil forms strongly suggests the development of a serious infection, which was not observed in the current study. No alteration was found in the biochemical serum exams, a finding also reported by other authors.

Table 3. Results of laboratory exams of eight patients

\begin{tabular}{|c|c|c|c|}
\hline Tests & $\mathbf{M}_{0}$ & $M_{1}$ & p level \\
\hline Leukocytes (thousand/mm³) & $12,063.30$ & $9,587.42$ & 0.07 \\
\hline Lymphocytes $\left(\mathrm{mm}^{3}\right)$ & $2,242.23$ & $2,058.80$ & 0.72 \\
\hline Monocytes $\left(\mathrm{mm}^{3}\right)$ & 817.11 & 747.87 & 0.72 \\
\hline Eosinophils $\left(\mathrm{mm}^{3}\right)$ & 106.37 & 192.20 & 0.28 \\
\hline Basophils $\left(\mathrm{mm}^{3}\right)$ & 6.04 & 129.09 & 0.44 \\
\hline Segmented neutrophils $\left(\mathrm{mm}^{3}\right)$ & $8,861.34$ & $6,328.46$ & 0.28 \\
\hline Bands $\left(\mathrm{mm}^{3}\right)$ & 30.21 & 131.00 & 0.47 \\
\hline Erythrocytes (millions/m³) & 5.01 & 4.10 & 0.01 \\
\hline Hemoglobin $(g / \%)$ & 15.06 & 12.36 & 0.01 \\
\hline Hematocrit (\%) & 44.60 & 36.98 & 0.01 \\
\hline Platelets (thousand $/ \mathrm{mm}^{3}$ ) & $221,250.00$ & $209,875.00$ & 0.72 \\
\hline Urea (mg/dL) & 37.12 & 32.75 & 0.72 \\
\hline Creatinine (mg/dL) & 0.88 & 0.90 & 1.00 \\
\hline Sodium (mmol/L) & 133.87 & 135.00 & 0.72 \\
\hline Potassium (mmol/L) & 3.73 & 4.07 & 0.22 \\
\hline Glucose (mg/dL) & 113.75 & 120.12 & 0.28 \\
\hline Proteins (g/dL) & 6.25 & 5.65 & 0.01 \\
\hline Albumin (g/dL) & 3.80 & 3.18 & 0.01 \\
\hline Globulin (g/dL) & 2.45 & 2.46 & 0.68 \\
\hline
\end{tabular}

$\mathrm{M}_{0}$ : admission; $\mathrm{M}_{1}$ : first weeks; $\mathrm{p}$ level: <0.05; Wilcoxon paired test. 
According to Table 4, at the moment of hospitalization $\left(\mathrm{M}_{0}\right)$, serum IL-6 levels were already higher than those of the controls. This finding suggests that these cytokines increase very rapidly under the burn stress, since they were collected, on average, five hours after the incident. Then, seven days after hospitalization $\left(M_{1}\right)$, the values had augmented more, as reported by several authors $(4,18)$. Similar data were reported by Yeh et al. (19), who found elevated cytokine levels two hours after the burn incident, thus revealing a rapid immune response in the face of this acute aggression (19). The present study demonstrated that serum TNF- $\alpha$ levels were already elevated at the moment of hospitalization $\left(M_{0}\right)$, but did not differ in relation to the control. Seven days after admission $\left(\mathrm{M}_{1}\right)$, these values had significantly elevated, as verified by several authors. Augmented serum TNF-a levels were observed in burn patients, as well as in patients with septic shock $(4,18-20)$. Previous studies also showed considerable elevations in TNF- $\alpha$ levels associated with sepsis and unfavorable prognosis in burn patients $(4,18-20)$.

Table 4. Results of immunological examinations

\begin{tabular}{llll}
\hline & Control (mean \pm SD) & $M_{0}($ mean \pm SD) & $M_{1}($ mean \pm SD) \\
\hline TNF- $\alpha(p g / m L)$ & $102.05 \pm 20.91$ & $119.37 \pm 19.50$ & $267.87 \pm 66.31$ \\
\hline IL-6 $(\mathrm{pg} / \mathrm{mL})$ & $101.80 \pm 16.19$ & $118.75 \pm 9.61$ & $277.38 \pm 48.23$ \\
\hline
\end{tabular}

$\mathrm{M}_{0}$ : admission; $\mathrm{M}_{1}$ : first week; SD: standard deviation.

To the best of our knowledge, there are no works in the literature comparing immune alterations and nutritional status. In the present study, there was no significant difference between serum cytokine levels and nutritional diagnosis, which may have occurred on account of the small number of patients, as displayed in Table 5.

Table 5. Correlation between serum levels of TNF- $\alpha$ and IL-6 in relation to the nutritional status at the moment of hospitalization

\begin{tabular}{cccc} 
& Mild obesity and obesity (median) & Normal (median) & p level \\
\hline TNF- $\alpha(\mathrm{pg} / \mathrm{mL})$ & $125.5(121.0-139.5)$ & $101.0(97.0-120.0)$ & 0.1939 \\
\hline IL-6 $(\mathrm{pg} / \mathrm{mL})$ & $117.00(111.5-121.0)$ & $121.0(111.0-131.5)$ & 0.6650 \\
\hline
\end{tabular}

Median and Wilcoxon paired test $(p<0.05)$. 
A burn patient is extremely susceptible to hospital infections. The infection risk is increased by the break of the protective barrier constituted by the skin, the most important tool against invasion by microorganisms $(5,7)$. Skin secretion culture is an important instrument for analyzing the nosocomial flora of all patients, since predominant microorganisms in burn lesions are part of the microbiota found in normal whole skin, as reported by several studies $(7,21,22)$. In the current work, it was observed that no patients presented microorganisms at the moment of admission. However, seven days after hospitalization, three bacteria were identified: Staphylococcus aureus, Enterobacter sp. and Pseudomonas aeruginosa (Table 6). The first was found at all studied sites, in agreement with other works $(5,7,21,22)$.

Table 6. Microbiological tests seven days after hospitalization

\begin{tabular}{c|c|c|c|c}
\hline Patients & $\begin{array}{c}\text { Nasal } \\
\text { mucosa }\end{array}$ & $\begin{array}{c}\text { Axillary } \\
\text { region }\end{array}$ & Burn site & Oropharynx \\
\hline $\mathbf{1}$ & S. aureus & S. aureus & S. aureus & S. aureus \\
\hline $\mathbf{2}$ & S. aureus & $\begin{array}{c}\text { Enterobacter } \\
\text { sp. }\end{array}$ & Enterobacter sp. & Enterobacter sp. \\
\hline $\mathbf{3}$ & Negative & Negative & $\begin{array}{c}\text { Pseudomonas } \\
\text { aeruginosa }\end{array}$ & $\begin{array}{c}\text { Pseudomonas } \\
\text { aeruginosa }\end{array}$ \\
\hline $\mathbf{4}$ & Negative & Negative & Negative & Enterobacter sp. \\
\hline $\mathbf{6}$ & S. aureus & Negative & Negative & Negative \\
\hline $\mathbf{7}$ & Negative & Negative & $\begin{array}{c}\text { Pseudomonas } \\
\text { aeruginosa }\end{array}$ & $\begin{array}{c}\text { Pseudomonas } \\
\text { aeruginosa }\end{array}$ \\
\hline $\mathbf{8}$ & Negative & Negative & Neudomonas & S. aureus \\
\hline
\end{tabular}

S. aureus: Staphylococcus aureus.

Given the importance of burn injury effects on victim survival, it is necessary to conduct further studies that include a greater number of burn patients, with the aim of minimizing alterations that this aggression can provoke. In this context, it is crucial to understand the nutritional, infectious and immunological aspects of the patient, so that better relief may be offered in response to burn injuries. It should be emphasized that burn patients are healthy individuals who suffered an acute aggression for which the organism is not prepared. 


\section{REFERENCES}

1. Pereima MJ, Leal M, Capella M, Goldberg P, Quaresma E, Araújo EJ, et al. Análise de 573 crianças com queimaduras internadas no Hospital Infantil Joana de Gusmão. Rev Bras Queimad. 2001;1(1):41-8.

2. Vale ECS. Primeiro atendimento em queimaduras: a abordagem do dermatologista. An Bras Dermatol. 2005;80(1):9-19.

3. Suri MP, Dhingra VJ, Raibagkar SC, Mehta DR. Nutrition in burns: need for an aggressive dynamic approach. Burns. 2006;32(7):880-4.

4. Ozbalkan Z, Aslar AK, Yildiz Y, Aksaray S. Investigation of the course of proinflammatory and anti-inflmmatory cytokines after burn sepsis. Int J Clin Pract. 2004; 52(2):125-9.

5. Ramakrishnan MK, Sankar J, Venkatraman J, Ramesh J. Infections in burn patients: experience in a tertiary care hospital. Burns. 2006;32(5):594-6.

6. Hettiaratchy S, Dziewulski P. ABC of burns. Introduction. Br Med J. 2004; 328(7452):1366-8.

7. Macedo JLS, Rosa SC, Macedo KCS, Castro C. Fatores de risco da sepse em pacientes queimados. Rev Col Bras Cir. 2005;32(4):173-7.

8. Saffle RJ. What's new in general surgery: burns and metabolism. J Am Coll Surg. 2003;196(2):267-89.

9. Prelack K, Dylewski M, Sheridan R. Practical guidelines for nutritional management of burn injury and recovery. Burns. 2007;33(1):14-24.

10. Berry MG, Evison D, Roberts AHN. The influence on body mass index on burn surface area estimated from the area of the hand. Burns. 2001;27(6):591-4.

11. Farrell RT, Gamelli RL, Aleem RF, Sinacore JM. The relationship of body mass index and functional outcomes in patients with acute burns. J Burn Care Res. 2008;29(1):102-8.

12. Herndon DN, Tompkins RG. Support of the metabolic response to burn injury. Lancet. 2004;363(9424):1895-902.

13. Pereira PCM. Interaction between infection, nutrition and immunity in tropical medicine. J Venom Anim Toxins incl Trop Dis. 2003;9(2):163-73.

14. França TGD, Ishikawa LLW, Pezavento SFGZ, Minicucci FC, Cunha MLRS, Sartori A. Impact of malnutrition on immunity and infection. J Venom Anim Toxins incl Trop Dis. 2009;15(3):374-90. 
15. Sheridan RL, Szyfelbein SK. Trends in blood conservation in burn care. Burns. 2001;27(3):272-6.

16. Lehnhardt M, Jafari HJ, Druecke D, Steinstraesser L, Steinau HU, Klatte W, et al. A qualitative and quantitative analysis of protein loss in human burn wounds. Burns. 2005;31(2):159-67.

17. Barati M, Alinejad F, Bahar MA, Tabrisi S, Shamshiri AR, Bodouhi N, et al. Comparison of WBC, ESR, CRP and PCT serum levels in septic and non-septic burn cases. Burns. 2008;34(6):770-4.

18. Yeh FL, Shen HD, Fang RH. Deficient transforming growth factor beta and interleukin-10 responses contribute to the septic death of burned patients. Burns. 2002;28(7):631-7.

19. Yeh FL, Lin WL, Shen HD. Changes in circulating levels of an anti-inflammatory cytokine interleukin 10 in burned patients. Burns. 2000;26(5):454-9.

20. Dehne MG, Sablotzki A, Hoffmann A, Muhling J, Dietrich FE, Hempelmann G. Alterations of acute phase reaction and cytokine production in patients following severe burn injury. Burns. 2002;28(6):535-42.

21. Church D, Elsayed S, Reid O, Winston B, Lindasy R. Burn wound infections. Clin Microbiol. 2006;19(2):403-34.

22. Macedo JLS, Santos JB. Nosocomial infections in a Brazilian burn unit. Burns. 2006;32(4):477-81. 